\title{
Biochar Enhanced Growth and Biological Nitrogen Fixation of Wild Soybean (Glycine max subsp. soja Siebold \& Zucc.) in a Coastal Soil of China
}

\author{
Shaojing Yin ${ }^{1,+}$, Fengyue Suo ${ }^{1,+}$, Qingxian Kong ${ }^{1}$, Xiangwei You ${ }^{1, *}$, Xin Zhang ${ }^{1}$, Yuan Yuan ${ }^{1} \mathbb{D}$, Xueyang Yu $^{1}$, \\ Yadong Cheng ${ }^{1}$, Ruixue Sun ${ }^{1}$, Hao Zheng ${ }^{2,3}$, Chengsheng Zhang ${ }^{1} \mathbb{D}$ and Yiqiang Li ${ }^{1, *}$
}

Citation: Yin, S.; Suo, F.; Kong, Q.; You, X.; Zhang, X.; Yuan, Y.; Yu, X.; Cheng, Y.; Sun, R.; Zheng, H.; et al. Biochar Enhanced Growth and Biological Nitrogen Fixation of Wild Soybean (Glycine max subsp. soja Siebold \& Zucc.) in a Coastal Soil of China. Agriculture 2021, 11, 1246. https://doi.org/10.3390/ agriculture11121246

Academic Editor: Bernhard Huchzermeyer

Received: 10 November 2021 Accepted: 6 December 2021 Published: 9 December 2021

Publisher's Note: MDPI stays neutral with regard to jurisdictional claims in published maps and institutional affiliations.

Copyright: (c) 2021 by the authors. Licensee MDPI, Basel, Switzerland. This article is an open access article distributed under the terms and conditions of the Creative Commons Attribution (CC BY) license (https:// creativecommons.org/licenses/by/ $4.0 /)$.
1 Marine Agriculture Research Center, Tobacco Research Institute, Chinese Academy of Agricultural Sciences, Qingdao 266101, China; yin1265298802@163.com (S.Y.); suofengyue@caas.cn (F.S.); qingxiankong@163.com (Q.K.); Z17863997311@163.com (X.Z.); yuanyuan03@caas.cn (Y.Y.); yuxueyang@caas.cn (X.Y.); chengyadong@caas.cn (Y.C.); sunruixue@caas.cn (R.S.); zhangchengsheng@caas.cn (C.Z.)

2 Ministry of Education, Frontiers Science Center for Deep Ocean Multispheres and Earth System, Key Laboratory of Marine Environment and Ecology, Institute of Coastal Environmental Pollution Control, Ocean University of China, Qingdao 266100, China; zhenghao2013@ouc.edu.cn

3 Laboratory for Marine Ecology and Environmental Science, Qingdao National Laboratory for Marine Science and Technology, Qingdao 266237, China

* Correspondence: youxiangwei@caas.cn (X.Y.); liyiqiang@caas.cn (Y.L.)

+ These two authors contributed equally to this work.

Abstract: The high salinity and nutrient deficiency in degraded coastal soil restricts crop growth and grain production. The development of effective and novel technology for coastal soil remediation is of great requirement. The effect of wood waste biochar (WB) on the growth and biological nitrogen fixation of wild soybean (Glycine max subsp. soja Siebold \& Zucc.), a legume with high economic values and salt tolerance in coastal soil, were explored using a 42-day pot experiment. With the optimal rate of WB addition $(1.5 \%, w / w)$, the biomass and plant height of wild soybean increased by $55.9 \%$ and $28.3 \%$, respectively. WB addition enhanced the photosynthesis (chlorophyll content) and biological nitrogen fixation (nodule number) of the wild soybean. These results may attribute to the improvement of the soil properties including the $\mathrm{SOM}, \mathrm{NO}_{3}{ }^{-}-\mathrm{N}$ content, and WHC. In addition, the shifted bacterial community following WB addition in the coastal soil favored the nitrogen fixation of wild soybean, which was evidenced by the increased abundance of nifH gene and Pseudarthrobacter, Azospirillum, and Rhizobiales. The results of our study suggested the potential of using biochar-based technology to reclaim the coastal degraded soils and enhance the crop growth to ensure food security.

Keywords: wild soybean; biochar; biological nitrogen fixation; bacterial community; coastal soil

\section{Introduction}

Coastal soils are important reserve land resources for food production; however, there is an area of 3.4-9.8 billion $\mathrm{m}^{2}$ of them degrading every year worldwide $[1,2]$. Coastal soils face a series of problems, including high $\mathrm{pH}$ value and salinity, low water and nutrient retention capacity, poor air and water permeability, and low soil organic carbon concentrations [3-5]. These problems restricted the sustainable development of agriculture and food safety [6]. Therefore, the development of effective, low cost, and environmentally friendly technologies for reclaiming coastal soil is of great importance for solving the problem of cultivated land shortage in the coastal region.

Biochar, a carbon-rich material produced by the pyrolysis of biomass under anaerobic conditions [7], has attracted increasing attention in environment remediation and soil amendment in the past decades [8-10]. There have been many studies that have reported the benefits of applying biochar as a soil ameliorant, such as mitigating climate 
change [11], improving soil fertility [12,13], and increasing plant productivity [14]. Some studies investigated the feasibility of using biochar for coastal soil amelioration $[15,16]$. The potential benefits of biochar application in coastal soils include decreasing the salinity and $\mathrm{pH}$, improving the soil properties, increasing soil nutrient bioavailability, and enhancing plant growth $[17,18]$. However, the improper utilization of biochar may also result in little or negative effects on the coastal soil [19]. The inconsistency could attribute to the diversity in biochar characteristics [20], biochar application dosage [21], soil properties [22,23], and plant species [24]. Therefore, more studies should be conducted to investigate the effect of biochar on the growth of specific plant species in the coastal soils.

Wild soybean (Glycine max subsp. soja Siebold \& Zucc.) [25] is an annual legume plant and can adapt to the saline-alkaline habitat in the Yellow River Delta region [19]. Due to the high levels of phytochemicals that could reduce the risk of heart disease, stroke, and diabetes, wild soybean is considered as the ideal halophyte crop, which has high economic values and is cultivated in the coastal soil of Yellow River Delta region [26]. As a legume plant, wild soybean had the ability of biological nitrogen fixation, which was a process in which diazotrophs fix and convert atmospheric $\mathrm{N}_{2}$ to bioavailable ammonia and is catalyzed by nitrogenase enzymes [27]. Legume-Rhizobium symbiosis provided nearly half of the $\mathrm{N}$ used in agriculture worldwide, markedly minimizing the application of chemical fertilizers and promoting the friendly relationship between human and environment [28]. Some previous studies showed the positive effects of biochar on the growth and quality of legumes by regulating soil $\mathrm{pH}$ [29], influencing soil bulk density and water-holding capacity [30], providing higher amounts of nutrients [31], and increasing the abundance of $\mathrm{N}$-fixing microorganism (Sinorhizobium genera) [31]. Xiu et al. [27] showed that Albic soil amended with corn straw biochar could promote the biological nitrogen fixation of soybean and then increase the crop yield. Liu et al. [32] observed that rice straw biochar could affect the nodule number, nodule fresh weight, nifH gene abundance, nitrogen fixation rate, and the soil nitrogen-fixing bacteria in an alkaline soil. However, little information is known about the effect of biochar on the growth and nitrogen fixation of legume plants in coastal soils.

Soil microorganisms also played an important role in soil health and plant growth [33]. The changes in soil properties and the habitats provided for microorganisms with biochar addition might enhance the microbial diversity and shift their community structure, which ultimately affects plant growth. Liao et al. [34] found that the apple wood biochar could decrease the relative abundances of Proteobacteria and increase the relative abundances of Bacteroidetes and Firmicutes in the soil, and eventually, enhanced the plant performance of maize. Meng et al. [35] found that wheat straw biochar increased the diversity of beneficial bacterial and fungal taxa in the rhizosphere of wheat seedlings and had a slight growth-promoting effect on the wheat seedlings. However, the effect of biochar on the soil microorganisms in the coastal soil with legumes growth was not clear, and the relationship between legumes growth and response of soil microorganism to biochar addition should be investigated [36].

We hypothesized that wood waste biochar (WB) could enhance the growth of wild soybean in coastal soil by improving nitrogen fixation and shift the soil microbial community. Therefore, in this study, a 42-day pot experiment was carried out. The objectives of this study were to (1) investigate the effect of WB on the growth of wild soybean at different application rates in coastal soil, (2) reveal the responses of soil microbial community to biochar application, and (3) explore the mechanisms of wild soybean response to WB amendments. This study provided potential ways to develop biochar technologies to amend coastal soil.

\section{Materials and Methods}

\subsection{Biochar Preparation and Soil Sampling}

Two weeks before the pot experiment, WB was prepared by slow pyrolyzing the wood waste at $450{ }^{\circ} \mathrm{C}$ for $6 \mathrm{~h}$ [11]. The surface soil $(0-20 \mathrm{~cm})$ and wild soybean was collected 
from Dongying $\left(118^{\circ} 67^{\prime} \mathrm{N}, 37^{\circ} 42^{\prime} \mathrm{E}\right)$ of the Yellow River Delta, China. The soil sample was thoroughly homogenized after air-dried and passed through a 2-mm sieve. The selected chemical and physical properties of biochar and soil are shown in Table S1.

\subsection{Pot Experiment}

WB was incorporated into the prepared soil sample at rates of $0(\mathrm{CK}), 1.5 \%$, or $5 \%$, $w / w(1.5 \% \mathrm{WB}, 5 \% \mathrm{WB})$. Soil samples $(500 \mathrm{~g})$ with or without WB were put into the plastic pot $(11 \mathrm{~cm}$ in diameter $\times 9 \mathrm{~cm}$ in depth) and then incubated for seven days at $60 \%$ maximum water holding capacity (WHC). Ten seeds of wild soybean collected from the Yellow River Delta last year were sowed in each pot and allowed to grow for 5 days after germination, then the best three seedlings were used for the experiment. All the experiments were conducted in triplicate. The pots were incubated in a greenhouse with $50-60 \%$ maximum WHC and with the temperature of $24{ }^{\circ} \mathrm{C} / 16^{\circ} \mathrm{C}$ at day/night. The pots were moved randomly every three days to keep conditions uniform. After six weeks, the soil of whole pot and wild soybean samples were collected. One portion of the collected soil samples was stored at $-80.0^{\circ} \mathrm{C}$ to analyze the microbial communities, and the other portion was used to measure the physicochemical properties after air-drying.

\subsection{Sample Analysis}

The plants were carefully harvested with roots. Each plant was separated into two parts (shoot and root), and the fresh biomass of each part and the plant height were measured. The roots were washed carefully with running water and the nodules numbers were recorded. The content of chlorophyll a and chlorophyll $b$ in the leaves of wild soybean was measured by the method of Zeeshan et al. [37]. The fresh leaf of the wild soybean was cut $(100 \mathrm{mg})$ and extracted with $10 \mathrm{~mL} 80 \%$ acetone at $-4{ }^{\circ} \mathrm{C}$ and then centrifuged at 10,000 rpm for $10 \mathrm{~min}$. The supernatant was recorded using a Shimadzu UV-2700 spectrophotometer at 645 (W645) and 663 (W663) nm wavelength to get the content of chlorophyll a, b. Final calculations were conducted using the following relations [38]:

$$
\begin{aligned}
& \text { Chlorophyll a }\left(\mathrm{mg}^{\mathrm{g}} \mathrm{g}^{-1}\right)=12.21 \mathrm{~W} 663-2.81 \text { W645 } \\
& \text { Chlorophyll b }\left(\mathrm{mg} \cdot \mathrm{g}^{-1}\right)=20.13 \mathrm{~W} 645-5.03 \mathrm{~W} 663
\end{aligned}
$$

Several parameters of the root were measured using a WinRHIZO (Epson Perfection V700 Photo Scanner, Epson, Japan) to get the root morphology, including length, surface area (SA), average diameter (AD), and tips.

For the soil samples, after being extracted by water at a ratio of $1: 5(\mathrm{~m} / \mathrm{v})$, the electrical conductivity $(\mathrm{EC})$, soil $\mathrm{pH}$, and soil salt content was determined using a conductivity meter (DDSJ-308A, INESA, Shanghai, China), pH meter (AB150, Fisher Scientific, Waltham, Massachusetts, USA), and residue-drying method. SOM was measured using a potassium dichromate oxidation method. WHC were measured by weight difference subtraction. The content of soil ammonium nitrogen $\left(\mathrm{NH}_{4}{ }^{+}-\mathrm{N}\right)$ and nitrate nitrogen $\left(\mathrm{NO}_{3}{ }^{-}-\mathrm{N}\right)$ were determined by segmented flow analysis (San++, Skalar, Netherlands) after being extracted by $1.0 \mathrm{~mol} \mathrm{~L}^{-1} \mathrm{KCl}$.

\subsection{Extraction of DNA and Quantitative Analysis of the nifH Gene}

DNA was extracted from $0.5 \mathrm{~g}$ fresh soil from the whole pot using the Fast DNA SPIN kit for Soil (MP Biomedicals, Santa Ana, California, USA) according to the manufacturer's instruction. After extraction, the quantity, integrity, and quality of the DNA were assessed by $1.0 \%$ agarose gel electrophoresis followed by staining in ethidium bromide and visualization in UV light. The DNA was further quantified by an NanoDrop-100 spectrophotometer (Thermo Fisher Scientific, Waltham, MA, USA).

Quantitative PCR was performed to quantify the relative abundance of the nifH gene in the soil samples with the primers nifH-F and nifH-R. Details of the qPCR reaction conditions were according to the method reported by Zhang et al. [38]. The standard 
curves were generated using triplicate 10-fold dilutions of plasmid DNA with inserted nifH gene.

\section{5. $16 S$ rRNA Gene Sequence Analysis of the Microorganism}

DNA was extracted from $0.5 \mathrm{~g}$ soil samples using the E.Z.N.A. ${ }^{\circledR}$ soil DNA Kit (Omega Bio-tek, Norcross, GA, USA) according to manufacturer's instructions. The extract was checked with $1 \%$ agarose gel and then determined with NanoDrop 2000 UV-vis spectrophotometer (Thermo Scientific, Wilmington, NC, USA). The V3 and V4 regions of the 16S rRNA gene were amplified using the forward primers $338 \mathrm{~F}$ and $806 \mathrm{R}$ by an ABI GeneAmp ${ }^{\circledR}$ 9700 PCR thermocycler (ABI, Waltham, MA, USA). The PCR cycle conditions were according to the method reported by Liu et al. [39]. AxyPrep DNA Gel Extraction Kit (Axygen Biosciences, Union City, CA, USA) was used to purified the PCR product extracted from $2 \%$ agarose gel. The Illumina HiSeq 2500 sequencing platform (Illumina, San Diego, CA, USA) was used to analysis the high-throughput sequencing of 16S rRNA and ITS gene amplicons. The above operations were conducted by Majorbio Bio-Pharm Technology Co. Ltd. (Shanghai, China).

\subsection{Statistical Analysis}

Differences in plant growth, nodulation, nifH gene copy numbers, root morphology, soil quality, and diversity indices due to biochar application were compared using one-way analysis of variance followed by Tukey's HSD test $(p<0.05)$ with SPSS $(20.0)$. Chao1 and Shannon diversity in all treatment were calculated with QIIME (Version 1.7.0). Principal component analysis (PCA) was performed by R software (Version 3.3.1). Students $t$-test was used to compare the significant difference among different treatment using $\mathrm{R}$ software (Version 3.5.1).

\section{Results}

\subsection{Effect of WB on Wild Soybean Growth}

The effects of WB on the fresh biomass and plant height of wild soybean are shown in Figure 1. The root biomass and plant biomass significantly increased 168.6-177.1\% and $48.2-55.9 \%$ by WB at the rates of $1.5 \%$ and $5 \%(w / w)$, respectively. However, there was no significant difference between the treatments of different rates $(1.5 \%, 5 \%, w / w)$. The treatment with $1.5 \% \mathrm{WB}$ also increased the plant height by $28.3 \%$ compared to CK. However, when amended with $5 \% \mathrm{WB}$, the effect of WB on plant height was not significant.
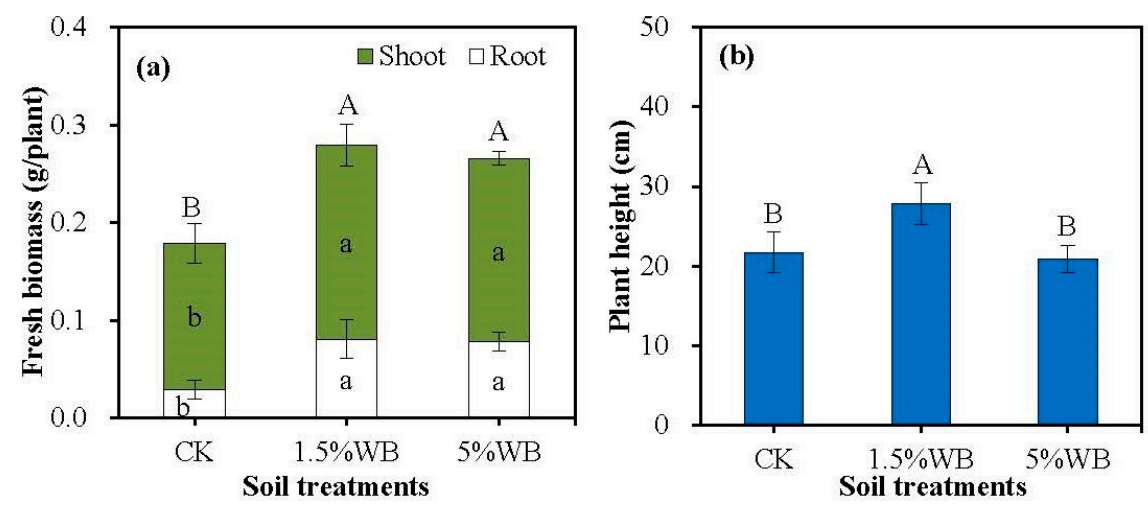

Figure 1. Effect of wood waste biochar (WB) on fresh biomass of root and shoot (a) and plant height (b) of the wild soybean. CK: soil treatment without WB amendment; $1.5 \% \mathrm{WB}$ and 5\% WB: soil amended with $\mathrm{WB}$ at the rate of $1.5 \%$ and $5.0 \%(w / w)$. Different small letters on the bars indicated the significant difference of fresh biomass in shoot and root between different treatments (Tukey's HSD test, $n=3, p<0.05)$. Different capital letters on the bars indicated significant difference of fresh biomass and height for the plant between different treatments (Tukey's HSD test, $n=3, p<0.05$ ). 


\subsection{Effect of WB on the Root Morphology of Wild Soybean}

As shown in Table 1, the root parameters of wild soybean, including root length, SA, and root volume, increased with the $\mathrm{WB}$ amendment. Compared to $\mathrm{CK}$, root length, $\mathrm{SA}$, and root volume increased by $39.01-125.27 \%, 61.52-132.51 \%$, and $83.9-134.48 \%$, respectively, with the amendment of WB by $1.5-5 \%(w / w)$. The WB amendment at $1.5 \%$ also increased the $\mathrm{AD}$ and tips of wild soybean, although not significantly. In addition, the dosage effects of WB amendment were not significant for root morphology of wild soybean, except for the root length.

Table 1. Effect of biochar on the root morphology of wild soybean in a coastal soil.

\begin{tabular}{cccccc}
\hline Treatment & Length $\mathbf{( c m )}$ & SA $\left.\mathbf{( c m}^{\mathbf{2}}\right)$ & Volume $\left.\mathbf{( c m}^{\mathbf{3}}\right)$ & AD $(\mathbf{m m})$ & Tips \\
\hline CK & $48.29 \pm 5.41 \mathrm{~b}$ & $4.15 \pm 0.69 \mathrm{~b}$ & $0.03 \pm 0.01 \mathrm{~b}$ & $0.27 \pm 0.05 \mathrm{a}$ & $288.00 \pm 37.03 \mathrm{a}$ \\
$1.5 \%$ WB & $67.13 \pm 9.88 \mathrm{~b}$ & $6.70 \pm 1.52 \mathrm{a}$ & $0.05 \pm 0.02 \mathrm{ab}$ & $0.32 \pm 0.03 \mathrm{a}$ & $346.33 \pm 59.18 \mathrm{a}$ \\
$5 \%$ WB & $108.78 \pm 18.15 \mathrm{a}$ & $9.65 \pm 1.66 \mathrm{a}$ & $0.07 \pm 0.01 \mathrm{a}$ & $0.28 \pm 0.01 \mathrm{a}$ & $279.33 \pm 47.38 \mathrm{a}$ \\
\hline
\end{tabular}

CK: soil treatment without wood waste derived biochar (WB); 1.5\% WB and 5\% WB: soil treatment with WB at the rate of $1.5 \%$ and $5.0 \%(w / w)$. SA: surface area; AD: average diameter; different letters in each column indicate significant difference at $p \leq 0.05$.

\subsection{Effect of WB on the Chlorophyll Content and Nodule Number of Wild Soybean}

The application of $1.5 \%$ WB significantly enhanced the chlorophyll a content and the total content of chlorophyll $(\mathrm{a}+\mathrm{b})$ by $16.9 \%$ and $13.6 \%$, respectively (Figure 2a). However, the higher application rate of WB $(5 \%, w / w)$ performed no significant effect on chlorophyll $\mathrm{a}$, compared to $\mathrm{CK}$, and decreased chlorophyll $\mathrm{b}$ and chlorophyll $(\mathrm{a}+\mathrm{b})$ by $22.57 \%$ and $21.42 \%$, respectively.
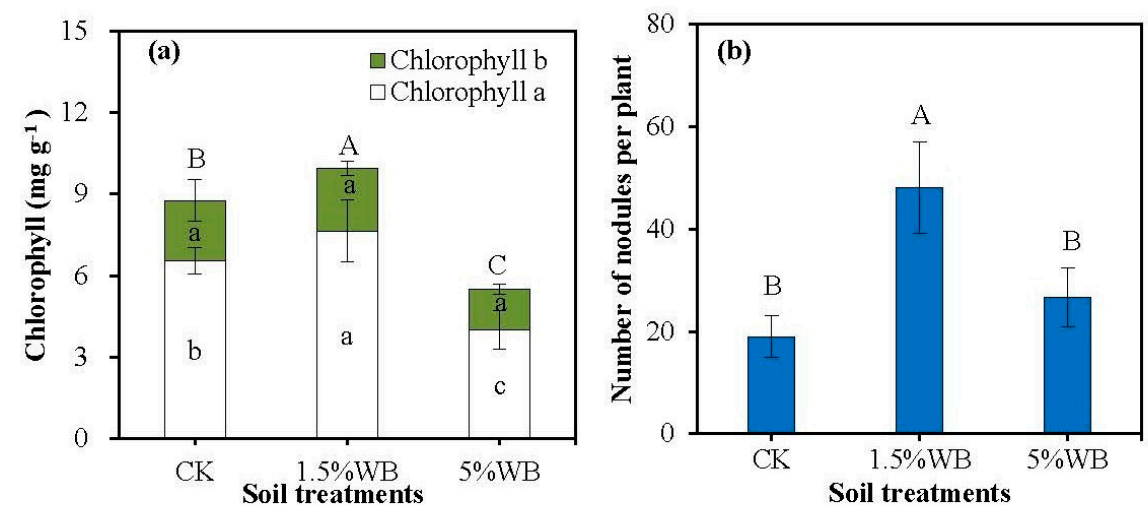

Figure 2. Effect of WB on chlorophyll a and chlorophyll $b$ (a) and the number of nodules per plant (b) of the wild soybean. CK: soil treatment without WB amendment; 1.5\% WB and 5\% WB: soil amended with WB at the rate of $1.5 \%$ and $5.0 \%(w / w)$. Different small letters on the bars indicated significant difference of chlorophyll a and chlorophyll b between different treatments (Tukey's HSD test, $n=3, p<0.05)$. Different capital letters on the bars indicated the significant difference of chlorophyll $\mathrm{a}+$ chlorophyll $\mathrm{b}$ and the number of nodules between different treatments (Tukey's HSD test, $n=3, p<0.05)$.

The number of nodules per plant increased from 19 to 48 and 27 after amended with $1.5 \%$ and $5 \% \mathrm{WB}$, respectively (Figure $2 \mathrm{~b}$ ). Although no significant change could be observed after the soil treated with 5\% WB, the application of $1.5 \%$ WB increased the nodule number of wild soybean significantly.

\subsection{Effect of WB on Soil Properties}

Effects of biochar on the soil physicochemical properties are shown in Table S2. The $\mathrm{WB}$ addition at the rate of $1.5-5 \%$ significantly increased SOM by $9.7-16.9 \%$. The $\mathrm{NO}_{3}{ }^{-} \mathrm{N}$ content significantly increased by $96.0 \%$ with low dosage of WB amendment $(1.5 \%, w / w)$; however, no significant effect was observed when the soil was amended with a high dosage 
of $5 \% \mathrm{WB}(w / w)$. The content of soil $\mathrm{NH}_{4}{ }^{+}-\mathrm{N}$ decreased by $53.5 \%$ after treated with $5 \%$ $\mathrm{WB}$, while no significant difference was observed between $\mathrm{CK}$ and 1.5\%WB treatment. Moreover, no significant difference of $\mathrm{pH}, \mathrm{EC}$, and salt content were observed between soil treatments with and without WB amendment.

\subsection{Effect of WB on the Diversity and Community of Soil Bacteria}

$\mathrm{WB}$, at an application rate of $1.5 \%$, significantly enhanced the growth performance of wild soybean (Figure 1); therefore, the diversity and community response of soil bacteria to $1.5 \% \mathrm{WB}$ addition was also investigated. Soil treatment with $1.5 \% \mathrm{WB}$ addition increased the Shannon index and Chao1 index by $3.71 \%$ and $9.78 \%$, although the increase was not significant (Figure 3a). The PCA results identified two principal components that could explain $35.0 \%$ (PC1) and 18.7\% (PC2) of the data variations. Samples from CK and $1.5 \%$ WB tended to cluster together and were clearly separated from each other, which evidenced the significant shift of soil bacterial community with WB amendment (Figure 3b).
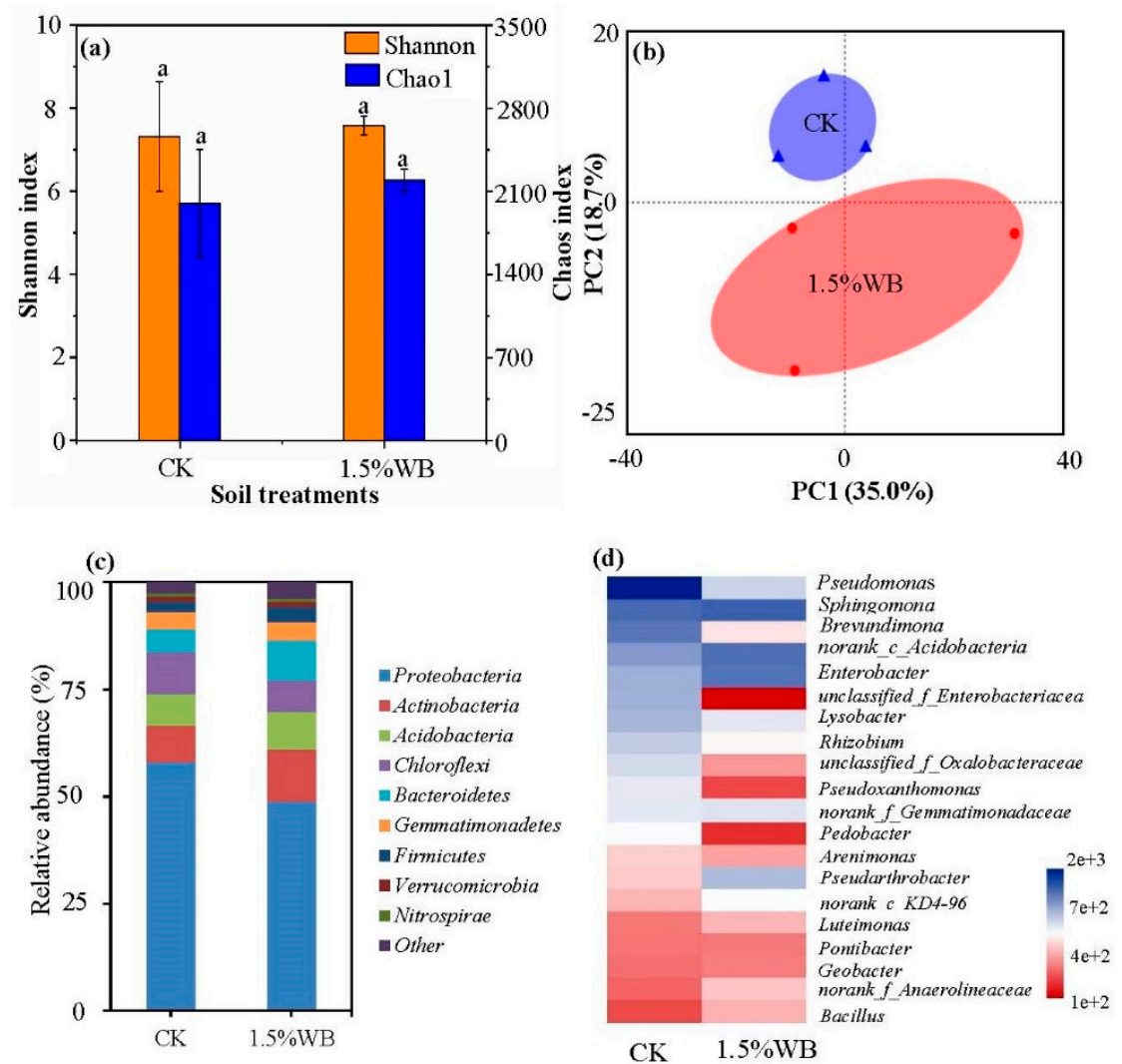

Figure 3. Effect of WB on the bacterial community in the coastal soils planted with wild soybean. The richness (Chao1) and diversity (Shannon) index for the soil bacterial community (a). Principal component analysis (PCA) of bacterial community composition based on the Bray-Curtis similarity (b). Relative abundance of the top 10 bacterial phyla (c). Heat map of the top 20 bacterial genera (d). CK: soil treatment without WB amendment; $1.5 \%$ WB: soil amended with WB at the rate of $1.5 \%$ $(w / w)$. Different small letters on the bars indicate significant difference between different treatments (Tukey's HSD test, $n=3, p<0.05$ ).

The relative abundance of bacteria at the phylum levels among all the treatments is shown in Figure 3c. Proteobacteria, Actinobacteria, Bacteroidetes, Acidobacteria, Chloroflexi, and Gemmatimonadetes were the six most dominant phyla, which accounted for over $90 \%$ of the bacterial sequences. The abundance of Proteobacteria, which was the most abundant phylum decreased by $15.64 \%$ with $1.5 \%$ WB amendment, while the abundance of Actinobacteria increased by $40.04 \%$. A heatmap was employed to describe the top 20 most abundant genera in the soil treatments with or without WB amendment 
(Figure 3d). The abundance of 9 bacteria genera decreased and 11 of them increased after the soil added with 1.5\% WB $(w / w)$. For example, Pseudarthrobacter, Brevundimonas, unclassified_f_Enterobacteriaceae, and Lysobacter was decreased by $56.3 \%, 61.49 \%$, $84.44 \%$, and $29.56 \%$. However, Sphingomonas, norank_c_Acidobacteria, Enterobacter, norank_f_Gemmatimonadaceae, and Pseudarthrobacter increased by $3.74 \%, 20.95 \%, 33.81 \%$, $5.04 \%$, and $98.79 \%$, respectively. Metastat analysis was employed to study the species with significant differences at genus level for studied soils. As demonstrated in Figure 4, significant differences were found in the relative abundance of ten genera between CK and 1.5 WB. The abundance of Pseudarthrobacter, Rhodococcus, Azospirillum, Cytophaga, Thioalkalispira, Norank_f_FFCH7168, Rhizobiales, Norank_o_Armatimonadales, Vicinamibacter, and Sporpcytophaga was higher in $1.5 \%$ WB treatment than that in CK.
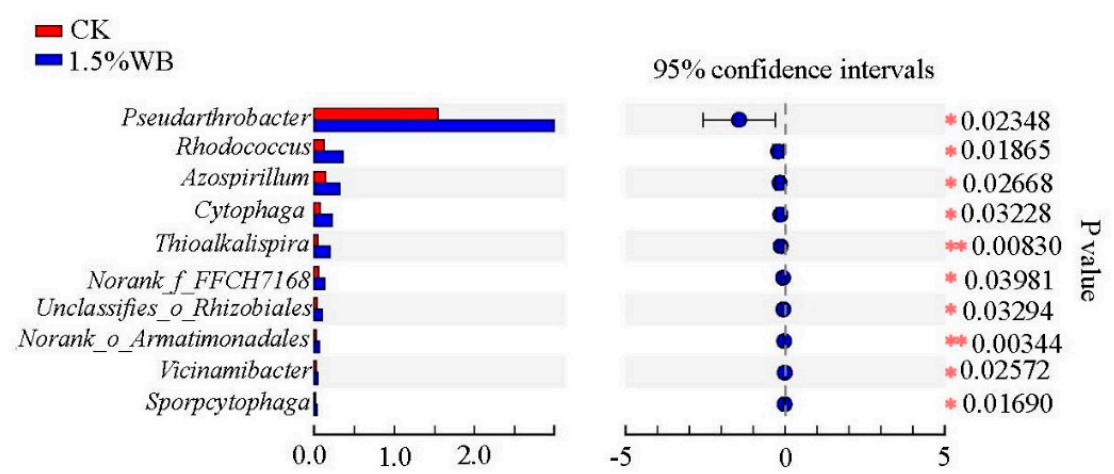

Figure 4. Extended error bar plot showing the ten most abundant genera with significant differences between different treatments in coastal soils without and with $\mathrm{WB}$ addition at the rate of $1.5 \%$. CK: soil treatment without WB amendment; 1.5\% WB: soil amended with WB at the rate of $1.5 \%$ $(w / w)$. Statistically significant differences among the relative bacterial abundance at genus level in the different soils were performed by metastats analysis.

The abundance of $\mathrm{N}_{2}$-fixing bacteria was estimated by quantifying nifH copy numbers in each treatment. The abundance of nifH gene significantly increased by $41.9 \%$ after amended with WB at the rate of $1.5 \%$ (Figure 5). However, no significant difference of the abundance of nifH gene was observed in the 5\% WB amendment.

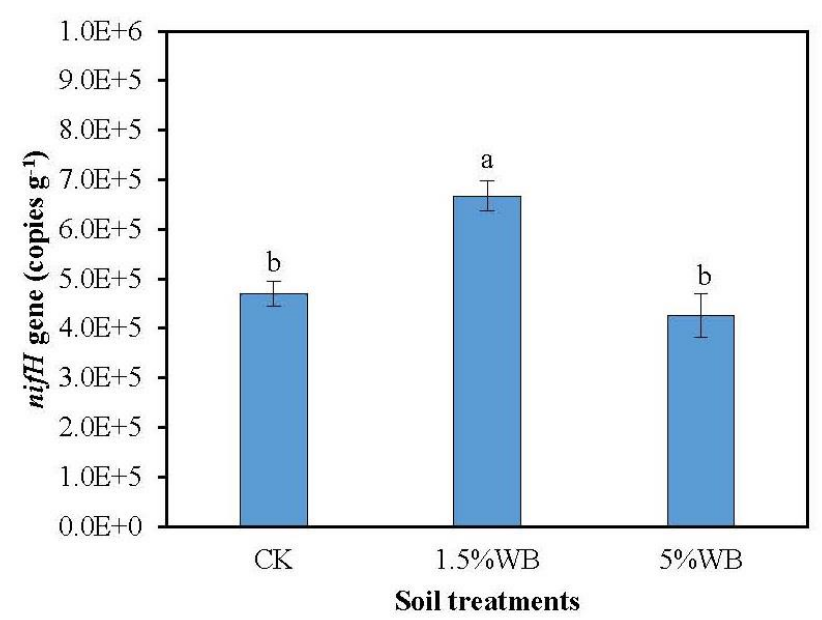

Figure 5. Effect of WB on nifH gene abundance in the coastal soil. CK: soil treatment without WB amendment; $1.5 \% \mathrm{WB}$ and 5\% WB: soil amended with WB at the rate of $1.5 \%$ and $5.0 \%(w / w)$. Different small letters on the bars indicated significant difference between different treatments (Tukey's HSD test, $n=3, p<0.05$ ). 


\section{Discussion}

\subsection{Response of Wild Soybean Growth to WB Amendments}

The growth of wild soybean could be promoted by the addition of WB at low rate $(1.5 \%, w / w)$. Cui et al. [40] also found that the biomass of Sesbania cannabina firstly increased and then decreased with increasing Spartina alterniflora biochar addition in a costal soil, suggesting that excessive application rate of biochar may inhibit plant growth and productivity. The excessive application of the amendments may not only suppress the growth of crop, but also increase agricultural production cost [20]. This phenomenon may attribute to the dissolution of salts cations including $\mathrm{K}^{+}, \mathrm{Ca}^{2+}$, and $\mathrm{Mg}^{2+}$ from biochars [18]. Thus, the quantity of the biochar or biochar-based amendment should be affirmed before application. There were also many researchers reported that biochar incorporation into the saline-alkali soil could enhance plant growth [40,41]. Zhao et al. [17] found that the yields of corn increased by $50.09 \%$ after the saline-alkali land treated with corn straw biochar at a rate of 20 ton ha ${ }^{-1}$. Biochar from Solidago canadensis L. pyrolyzed at $550{ }^{\circ} \mathrm{C}$ and $600{ }^{\circ} \mathrm{C}$ sharply increased fresh biomasses of Brassica chinensis L. by $71.94 \%$ and $59.70 \%$ and dry biomasses by $52.36 \%$ and $22.40 \%$, respectively, in a coastal soil [2]. The application of WB improved the root growth obviously. The root length, SA, and root volume in the WB treatments were higher than $\mathrm{CK}$, implying that the root system expanded after the addition of WB. The high surface area and various functional groups of biochar could decrease the loss of nutrient and then provide more nutrients for the plant [27].

The chlorophyll content could reflect the photosynthetic activities in a complex manner and measure the reaction of plant to the environmental stress and nutritional status [18]. The amendment of $1.5 \% \mathrm{WB}$ in soil improved the content of chlorophyll, which possibly increased the photosynthetic activities, resulting in better wild soybean growth. The increase in chlorophyll content improved photosynthetic efficiency and enhanced plant tolerance against stress. However, there were also studies showed that the application of biochar in coastal soil had no effect on the content of the leaf chlorophyll [8,39], which might be related to the biochar characteristics, soil properties, and crop types [18,42].

Legume root nodules could influence the nitrogen fixation in legume crops and then affect the growth of legume roots [27,43]. The root nodule number of the $1.5 \% \mathrm{WB}$ treatments was higher than those of CK. Wang et al. [44] also found that the numbers and weight of nodules increased from 10 to 24 and 0.07 to $0.20 \mathrm{~g}$, respectively, after being amended with $10 \%$ bamboo biochar $(w / w)$. Scheifele et al. [45] reported biochar could affect the root nodulation and biological nitrogen fixation. The soil properties, including $\mathrm{pH}$ and nutrients, can affect the degree of legume nodulation and these properties could be enhanced by biochar (Table S2) [46]. Quilliam et al. [47] reported that biochar could enhance the formation of nodules by improving the chemical signal transmission between the root and nodules and enhancing the formation of root derived polyphenolic signaling compounds such as flavonoids and eventually enhance the formation of nodules.

\subsection{Response of Soil Properties to WB Amendments}

Our findings showed that WB could improves soil properties and nutrient content, which agreeed with previous studies [15,48]. The addition of WB increased the value of SOM and WHC (Table S2) due to the high C content and porosity of biochar, respectively [49]. Conversely, WB had little influence on the soil pH (Table S2), which might attribute to the high buffering capacity of the coastal soil. WB had a positive effect on the $\mathrm{NO}_{3}{ }^{-}-\mathrm{N}$ content in soil at a lower application rate $(1.5 \%, w / w)$, but had a negative effect at a higher rate $(5 \%, w / w)$, indicating that the application rate of biochar should be in a proper level. Cai et al. [41] also found that Spartina alterniflora biochar significantly increased the content of $\mathrm{NO}_{3}{ }^{-}-\mathrm{N}$ in a costal soil. There were significant positive relationships between nodule numbers and $\mathrm{NO}_{3}{ }^{-}-\mathrm{N}$ content, and $\mathrm{WHC}$ in the soil also has positively correlated with root length, implying that the $\mathrm{NO}_{3}{ }^{-}-\mathrm{N}$ and WHC in soil may be the most crucial factors to explain the change of nodule number and root length, respectively (Table S3). 
Thus, the improvement in root morphological development would benefit plants growth under biochar application by alleviating nutrient and water deficiency in coastal soils.

\subsection{Response of Soil Bacteria to WB Amendments}

Soil microorganisms are essential to the soil nutrient cycling, decomposition, and energy flow, and these processes can be affected by the addition of biochar, which can change the diversity and structure of soil microorganisms [50]. In this study, the abundances of Sphingomonas, norank_c_Acidobacteria, Enterobacter, norank_f_Gemmatimonadaceae, and Pseudarthrobacter were increased after $1.5 \% \mathrm{WB}$ addition. There are many reasons for the changes of bacterial community diversity and structure by biochar amendment. Firstly, biochar changes the physical and chemical properties of soil [48]. Secondly, biochar can provide direct nutrients for the soil bacteria [51]. Meanwhile, the large surface area and porosity of biochar supply space and attachment sites for bacteria to growth [33]. Moreover, the biochar had a high adsorption capacity and can absorb various soluble organic and inorganic substances, which was benefit for soil bacteria [52]. Sphingomonas was reported to be beneficial to plants' growth and to be distributed widely, always as potential antagonists of plant pathogens $[53,54]$. Enterobacter can reduce salinity stress for rice seedlings, resist to pathogenic bacterial and fungi and reduce the amount of ethylene in seed to promote plant growth [55]. The results further demonstrated that WB decreased the salt stress and promoted the plant growth in the costal soils.

\subsection{Potential Mechanisms of Biochar on N Fixation}

The abundance of Pseudarthrobacter was increased the most among the genera after $1.5 \% \mathrm{WB}$ addition. Some researches pointed out that Pseudarthrobacter were positively correlated with the concentration of soil $\mathrm{NH}_{4}{ }^{+}$in biofertilizer applicated for the soil continuous cropping American ginseng, confirmed that Pseudarthrobacter could promote plant growth by fixing atmospheric $\mathrm{N}$ into $\mathrm{NH}_{4}{ }^{+}$[56]. Azospirillum was a free-living bacteria for biological nitrogen fixation and had used as inoculant widely to promote plant growth [22]. Liu et al. [26] reported that the abundance of genera Azospirillum showed little changes among the fertilizer, straw, and biochar treatments in an alkaline soil. However, the research of Abujabhah et al. [57] showed strong positive correlations in Azospirillum abundance with increasing biochar addition in black clay loam soil, which was consistent with the results of this study. Rhizobiales was also reported as a $\mathrm{N}_{2}$-fixing bacteria [39]. The abundance of nifH genes is positively correlated with the rates of $\mathrm{N}_{2}$ fixation. The higher abundance of nifH gene observed in the 1.5\% WB amended soil of this study proved that optimal concentration biochar could promote biological nitrogen fixation. Overall, WB could increase the abundance of the $\mathrm{N}_{2}$-fixing bacteria and nifH gene in the coastal soil.

The correlation heatmap analysis of the relationships among the top 10 bacteria genera and the soil properties (EC, $\mathrm{pH}, \mathrm{SOM}, \mathrm{WHC}, \mathrm{NH}_{4}{ }^{+}-\mathrm{N}, \mathrm{NO}_{3}{ }^{-}-\mathrm{N}$, and salt content) were shown in Figure 6. In the CK treatment (Figure 6a), there was no significant correlation between soil properties and the top 10 bacteria genera. However, in the $1.5 \% \mathrm{WB}$ treatment (Figure $6 \mathrm{~b}$ ), WHC was positively correlated with Pseudomonas and salt content was negatively correlated with Enterobacter. These results indicated that biochar addition could shift the microbial communities by altering the soil properties. 


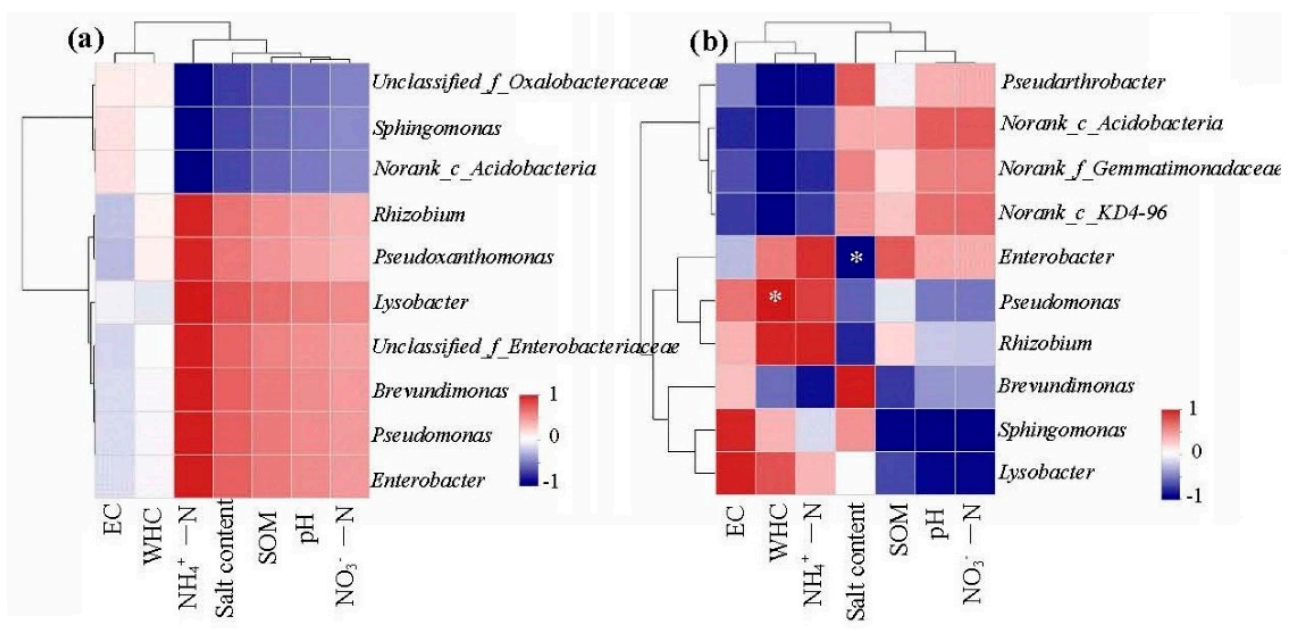

Figure 6. The Pearson correlation heatmap of soil properties and the relative abundance of bacterial community at genus level in the coastal soil without (a) and with (b) 1.5\% WB. EC: Electrical conductivity; SOM: Soil organic matter; $\mathrm{NH}_{4}{ }^{+}-\mathrm{N}$ : Ammonium nitrogen; $\mathrm{NO}_{3}{ }^{-}-\mathrm{N}$ : Nitrate nitrogen. Red indicated a positive correlation and blue indicated a negative correlation. The darker the color, the greater the correlation. ${ }^{*}$ Significant at $0.01<p<0.05$.

\section{Conclusions}

This study demonstrated that the application of $\mathrm{WB}$ at the rate of $1.5 \%$ promoted the wild soybean growth and biological nitrogen fixation in the coastal soil. These results were attributed to the enhanced soil properties, including $\mathrm{SOM}, \mathrm{WHC}$, and $\mathrm{NO}_{3}{ }^{-}-\mathrm{N}$ content, and increased abundance of beneficial bacteria such as Pseudarthrobacter, Azospirillum, and Rhizobiales and nifH gene with WB amendment. However, this experiment lasted for only 42 days and consisted of a pot experiment; a field experiment should be carried out to investigate the long-term effects of biochar on the soil properties and environmental benefits for coastal soil.

Supplementary Materials: The following are available online at https:/ /www.mdpi.com/article/10 .3390 /agriculture11121246/s1, Table S1: Selected chemical and physical properties of the soil and wood waste biochar (WB), Table S2: Effect of WB on the properties of coastal soil, Table S3: Pearson correlation coefficients of soil properties with physiology and growth parameters of wild soybean.

Author Contributions: Conceptualization, X.Y. (Xiangwei You); methodology, S.Y., X.Z. and Q.K.; software, F.S.; validation, Y.Y., X.Y. (Xueyang Yu), C.Z., Y.C. and R.S.; formal analysis, S.Y.; investigation, S.Y. and Q.K.; resources, Y.L.; data curation, X.Y. (Xiangwei You); writing-original draft preparation, F.S. and S.Y.; writing-review and editing, X.Y. (Xiangwei You) and H.Z.; project administration, Y.L.; funding acquisition, X.Y. (Xiangwei You), C.Z. and Y.L. All authors have read and agreed to the published version of the manuscript.

Funding: This work was funded by the Demonstration and Guidance Program for Technology PeopleBenefit in Qingdao (20-3-4-7-nsh), the Agricultural Science and Technology Innovation Program of China (ASTIP-TRIC07), the Science and Technology Demonstration Project of "Bohai Granary" of Shandong Province (2019BHLC002), and the Key Projects of Joint National Nature Science Foundation of China (NSFC)-Shandong fund (grant no. U1806206).

Institutional Review Board Statement: Not applicable.

Informed Consent Statement: Not applicable.

Data Availability Statement: Data are not publicly available, though the data may be made available on request from the corresponding author.

Conflicts of Interest: The authors declare no conflict of interest. 


\section{References}

1. Tang, J.; Zhang, S.; Zhang, X.; Chen, J.; He, X.; Zhang, Q. Effects of pyrolysis temperature on soil-plant-microbe responses to Solidago canadensis L.-derived biochar in coastal saline-alkali soil. Sci. Total Environ. 2020, 731, 138938. [CrossRef] [PubMed]

2. Xia, J.; Ren, R.; Zhang, S.; Wang, Y.; Fang, Y. Forest and grass composite patterns improve the soil quality in the coastal saline-alkali land of the Yellow River Delta, China. Geoderma 2019, 349, 25-35. [CrossRef]

3. Saifullah, D.S.; Naeem, A.; Rengel, Z.; Naidu, R. Biochar application for the remediation of salt-affected soils: Challenges and opportunities. Sci. Total Environ. 2018, 625, 320-335. [CrossRef]

4. Saboor, A.; Ali, M.A.; Ahmed, N.; Skalicky, M.; Danish, S.; Fahad, S.; Hassan, F.; Hassan, M.; Brestic, M.; Sabagh, A.; et al. Biofertilizer-Based Zinc Application Enhances Maize Growth, Gas Exchange Attributes, and Yield in Zinc-Deficient Soil. Agriculture 2021, 11, 310. [CrossRef]

5. Xiao, L.; Yuan, G.; Feng, L.; Bi, D.; Wei, J. Soil properties and the growth of wheat (Triticum aestivum L.) and maize (Zea mays L.) in response to reed (Phragmites communis) biochar use in a salt-affected soil in the Yellow River Delta. Agric. Ecosyst. Environ. 2020, 303, 107124. [CrossRef]

6. Yang, C.; Sun, J. Soil Salinity Drives the Distribution Patterns and Ecological Functions of Fungi in Saline-Alkali Land in the Yellow River Delta, China. Front. Microbiol. 2020, 11, 594284. [CrossRef]

7. Lehmann, J.; Joseph, S. (Eds.) Biochar for Environmental Management: Science, Technology and Implementation, 2nd ed.; Routledge: London, UK, 2015.

8. You, X.; Suo, F.; Yin, S.; Wang, X.; Zheng, H.; Fang, S.; Zhang, C.; Li, F.; Li, Y. Biochar decreased enantioselective uptake of chiral pesticide metalaxyl by lettuce and shifted bacterial community in agricultural soil. J. Hazard. Mater. 2021, 417, 126047. [CrossRef] [PubMed]

9. Awad, M.; Liu, Z.; Skalicky, M.; Dessoky, E.S.; Brestic, M.; Mbarki, S.; Rastogi, A.; EL Sabagh, A. Fractionation of Heavy Metals in Multi-Contaminated Soil Treated with Biochar Using the Sequential Extraction Procedure. Biomolecules 2021, 11, 448. [CrossRef]

10. Zheng, H.; Feng, N.; Yang, T.; Shi, M.; Wang, X.; Zhang, Q.; Zhao, J.; Li, F.; Sun, K.; Xing, B. Individual and combined applications of biochar and pyroligneous acid mitigate dissemination of antibiotic resistance genes in agricultural soil. Sci. Total Environ. 2021, 796, 148962. [CrossRef]

11. Zhang, C.; Zeng, G.; Huang, D.; Lai, C.; Chen, M.; Cheng, M.; Tang, W.; Tang, L.; Dong, H.; Huang, B.; et al. Biochar for environmental management: Mitigating greenhouse gas emissions, contaminant treatment, and potential negative impacts. Chem. Eng. J. 2019, 373, 902-922. [CrossRef]

12. Suo, F.; You, X.; Yin, S.; Wu, H.; Zhang, C.; Yu, X.; Sun, R.; Li, Y. Preparation and characterization of biochar derived from co-pyrolysis of Enteromorpha prolifera and corn straw and its potential as a soil amendment. Sci. Total Environ. 2021, $798,149167$. [CrossRef]

13. Yang, C.; Lu, S. Straw and straw biochar differently affect phosphorus availability, enzyme activity and microbial functional genes in an Ultisol. Sci. Total Environ. 2022, 805, 150325. [CrossRef] [PubMed]

14. You, X.; Yin, S.; Suo, F.; Xu, Z.; Chu, D.; Kong, Q.; Zhang, C.; Li, Y.; Liu, L. Biochar and fertilizer improved the growth and quality of the ice plant (Mesembryanthemum crystallinum L.) shoots in a coastal soil of Yellow River Delta, China. Sci. Total Environ. 2021, 775, 144893. [CrossRef]

15. Oladele, S.O.; Adeyemo, A.J.; Awodun, M.A. Influence of rice husk biochar and inorganic fertilizer on soil nutrients availability and rain-fed rice yield in two contrasting soils. Geoderma 2019, 336, 1-11. [CrossRef]

16. Gunarathne, V.; Senadeera, A.; Gunarathne, U.; Biswas, J.K.; Almaroai, Y.A.; Vithanage, M. Potential of biochar and organic amendments for reclamation of coastal acidic-salt affected soil. Biochar 2020, 2, 107-120. [CrossRef]

17. Zhao, W.; Zhou, Q.; Tian, Z.; Cui, Y.; Liang, Y.; Wang, H. Apply biochar to ameliorate soda saline-alkali land, improve soil function and increase corn nutrient availability in the Songnen Plain. Sci. Total Environ. 2020, 722, 137428. [CrossRef]

18. Yu, H.; Zou, W.; Chen, J.; Chen, H.; Yu, Z.; Huang, J.; Tang, H.; Wei, X.; Gao, B. Biochar amendment improves crop production in problem soils: A review. J. Environ. Manag. 2019, 232, 8-21. [CrossRef] [PubMed]

19. Zheng, H.; Wang, X.; Chen, L.; Wang, Z.; Xia, Y.; Zhang, Y.; Wang, H.; Luo, X.; Xing, B. Enhanced growth of halophyte plants in biochar-amended coastal soil: Roles of nutrient availability and rhizosphere microbial modulation. Plant Cell Environ. 2018, 41, 517-532. [CrossRef] [PubMed]

20. Zhou, Z.; Li, Z.; Zhang, Z.; You, L.; Xu, L.; Huang, H.; Wang, X.; Gao, Y.; Cui, X. Treatment of the saline-alkali soil with acidic corn stalk biochar and its effect on the sorghum yield in western Songnen Plain. Sci. Total Environ. 2021, 756, 143801. [CrossRef]

21. Pandit, N.R.; Mulder, J.; Hale, S.E.; Zimmerman, A.R.; Pandit, B.H.; Cornelissen, G. Multi-year double cropping biochar field trials in Nepal: Finding the optimal biochar dose through agronomic trials and cost-benefit analysis. Sci. Total Environ. 2018, 637-638, 1333-1341. [CrossRef]

22. Wu, L.; Wei, C.; Zhang, S.; Wang, Y.; Kuzyakov, Y.; Ding, X. MgO-modified biochar increases phosphate retention and rice yields in saline-alkaline soil. J. Clean. Prod. 2019, 235, 901-909. [CrossRef]

23. Zhang, Y.; Yang, C.; Zheng, Z.; Cao, B.; You, F.; Liu, Y.; Jiang, Z. Mechanism for various phytotoxicity of atrazine in soils to soybean: Insights from soil sorption abilities and dissolved organic matter properties. J. Environ. Manag. 2021, 297, 113220. [CrossRef] [PubMed]

24. Anyanwu, I.N.; Alo, M.N.; Onyekwere, A.M.; Crosse, J.D.; Nworie, O.; Chamba, E.B. Influence of biochar aged in acidic soil on ecosystem engineers and two tropical agricultural plants. Ecotox. Environ. Saf. 2018, 153, 116-126. [CrossRef] 
25. WFO. Glycine max subsp soja (Siebold \& Zucc.) H. Ohashi. 2021. Available online: http:/ /www.worldfloraonline.org/taxon/wfo0000192361 (accessed on 24 November 2021).

26. Liu, X.; Liu, C.; Gao, W.; Xue, C.; Guo, Z.; Jiang, L.; Li, F.; Liu, Y. Impact of biochar amendment on the abundance and structure of diazotrophic community in an alkaline soil. Sci. Total Environ. 2019, 688, 944-951. [CrossRef] [PubMed]

27. Xiu, L.; Zhang, W.; Wu, D.; Sun, Y.; Zhang, H.; Gu, W.; Wang, Y.; Meng, J.; Chen, W. Biochar can improve biological nitrogen fixation by altering the root growth strategy of soybean in Albic soil. Sci. Total Environ. 2021, 773, 144564. [CrossRef]

28. Lodwig, E.M.; Hosie, A.H.F.; Bourdès, A.; Findlay, K.; Allaway, D.; Karunakaran, R.; Downie, J.A.; Poole, P.S. Amino-acid cycling drives nitrogen fixation in the legume-Rhizobium symbiosis. Nature 2003, 422, 722-726. [CrossRef]

29. Farhangi-Abriz, S.; Torabian, S.; Qin, R.; Noulas, C.; Lu, Y.; Gao, S. Biochar effects on yield of cereal and legume crops using meta-analysis. Sci. Total Environ. 2021, 775, 145869. [CrossRef]

30. Azeem, M.; Sun, D.; Crowley, D.; Hayat, R.; Hussain, Q.; Ali, A.; Tahir, M.I.T.; Jeyasundar, P.G.S.A.; Rinklebe, J.; Zhang, Z. Crop types have stronger effects on soil microbial communities and functionalities than biochar or fertilizer during two cycles of legume-cereal rotations of dry land. Sci. Total Environ. 2020, 715, 136958. [CrossRef]

31. Araujo, J.; Díaz-Alcántara, C.A.; Urbano, B.; González-Andrés, F. Inoculation with native Bradyrhizobium strains formulated with biochar as carrier improves the performance of pigeonpea (Cajanus cajan L.). Eur. J. Agron. 2020, 113, 125985. [CrossRef]

32. Barbieri, R.; Coppo, E.; Marchese, A.; Daglia, M.; Sobarzo-Sánchez, E.; Nabavi, S.F.; Nabavi, S.M. Phytochemicals for human disease: An update on plant-derived compounds antibacterial activity. Microbiol. Res. 2017, 196, 44-68. [CrossRef] [PubMed]

33. Palansooriya, K.N.; Wong, J.T.F.; Hashimoto, Y.; Huang, L.; Rinklebe, J.; Chang, S.X.; Bolan, N.; Wang, H.; Ok, Y.S. Response of microbial communities to biochar-amended soils: A critical review. Biochar 2019, 1, 3-22. [CrossRef]

34. Liao, H.; Li, Y.; Yao, H. Biochar Amendment Stimulates Utilization of Plant-Derived Carbon by Soil Bacteria in an Intercropping System. Front. Microbiol. 2019, 10, 1361. [CrossRef]

35. Meng, L.; Sun, T.; Li, M.; Saleem, M.; Zhang, Q.; Wang, C. Soil-applied biochar increases microbial diversity and wheat plant performance under herbicide fomesafen stress. Ecotox. Environ. Saf. 2019, 171, 75-83. [CrossRef]

36. Yu, L.; Lu, X.; He, Y.; Brookes, P.C.; Liao, H.; Xu, J. Combined biochar and nitrogen fertilizer reduces soil acidity and promotes nutrient use efficiency by soybean crop. J. Soil. Sediment. 2017, 17, 599-610. [CrossRef]

37. Zeeshan, M.; Ahmad, W.; Hussain, F.; Ahamd, W.; Numan, M.; Shah, M.; Ahmad, I. Phytostabalization of the heavy metals in the soil with biochar applications, the impact on chlorophyll, carotene, soil fertility and tomato crop yield. J. Clean. Prod. 2020, 255, 120318. [CrossRef]

38. Zhang, M.; Xu, Z.; Teng, Y.; Christie, P.; Wang, J.; Ren, W.; Luo, Y.; Li, Z. Non-target effects of repeated chlorothalonil application on soil nitrogen cycling: The key functional gene study. Sci. Total Environ. 2016, 543, 636-643. [CrossRef] [PubMed]

39. Liu, J.; Han, J.; Zhu, C.; Cao, W.; Luo, Y.; Zhang, M.; Zhang, S.; Jia, Z.; Yu, R.; Zhao, J.; et al. Elevated atmospheric $\mathrm{CO}_{2}$ and nitrogen fertilization affect the abundance and community structure of rice root-associated nitrogen-fixing bacteria. Front. Microbiol. 2021, 12, 628108. [CrossRef] [PubMed]

40. Cui, Q.; Xia, J.; Yang, H.; Liu, J.; Shao, P. Biochar and effective microorganisms promote Sesbania cannabina growth and soil quality in the coastal saline-alkali soil of the Yellow River Delta, China. Sci. Total Environ. 2021, 756, 143801. [CrossRef]

41. Cai, J.; Jiang, F.; Liu, X.; Sun, K.; Wang, W.; Zhang, M.; Li, H.; Xu, H.; Kong, W.; Yue, F. Biochar-amended coastal wetland soil enhances growth of Suaeda salsa and alters rhizosphere soil nutrients and microbial communities. Sci. Total Environ. 2021, 788, 147707. [CrossRef]

42. Egamberdieva, D.; Wirth, S.; Behrendt, U.; Abd_Allah, E.F.; Berg, G. Biochar Treatment Resulted in a Combined Effect on Soybean Growth Promotion and a Shift in Plant Growth Promoting Rhizobacteria. Front. Microbiol. 2016, 7, 209. [CrossRef]

43. McGuiness, P.N.; Reid, J.B.; Foo, E. The influence of ethylene, gibberellins and brassinosteroids on energy and nitrogen-fixation metabolites in nodule tissue. Plant Sci. 2021, 305, 110846. [CrossRef]

44. Wang, C.; Alidoust, D.; Yang, X.; Isoda, A. Effects of bamboo biochar on soybean root nodulation in multi-elements contaminated soils. Ecotox. Environ. Saf. 2018, 150, 62-69. [CrossRef]

45. Scheifele, M.; Hobi, A.; Buegger, F.; Gattinger, A.; Schulin, R.; Boller, T.; Mäder, P. Impact of pyrochar and hydrochar on soybean (Glycine max L.) root nodulation and biological nitrogen fixation. J. Plant Nutr. Soil Sci. 2017, 180, 199-211. [CrossRef]

46. Farhangi-Abriz, S.; Torabian, S. Biochar improved nodulation and nitrogen metabolism of soybean under salt stress. Symbiosis 2018, 74, 215-223. [CrossRef]

47. Quilliam, R.S.; DeLuca, T.H.; Jones, D.L. Biochar application reduces nodulation but increases nitrogenase activity in clover. Plant Soil 2013, 366, 83-92. [CrossRef]

48. Mao, J.; Zhang, K.; Chen, B. Linking hydrophobicity of biochar to the water repellency and water holding capacity of biocharamended soil. Environ. Pollut. 2019, 253, 779-789. [CrossRef]

49. You, X.; Jiang, H.; Zhao, M.; Suo, F.; Zhang, C.; Zheng, H.; Sun, K.; Zhang, G.; Li, F.; Li, Y. Biochar reduced Chinese chive (Allium tuberosum) uptake and dissipation of thiamethoxam in an agricultural soil. J. Hazard. Mater. 2019, 390, 121749. [CrossRef]

50. Jia, R.; Qu, Z.; You, P.; Qu, D. Effect of biochar on photosynthetic microorganism growth and iron cycling in paddy soil under different phosphate levels. Sci. Total Environ. 2018, 612, 223-230. [CrossRef] [PubMed]

51. Zheng, H.; Wang, Z.; Deng, X.; Zhao, J.; Luo, Y.; Novak, J.; Herbert, S.; Xing, B. Characteristics and nutrient values of biochars produced from giant reed at different temperatures. Bioresour. Technol. Rep. 2013, 130, 463-471. [CrossRef] 
52. Chen, H.; Ma, J.; Wei, J.; Xin, G.; Yu, X.C.; Guo, H.; Zhao, Y.W. Biochar increases plant growth and alters microbial communities via regulating the moisture and temperature of green roof substrates. Sci. Total Environ. 2018, 635, 333-342. [CrossRef] [PubMed]

53. Hamann, C. Detection of polycyclic aromatic hydrocarbon degradation genes in different soil bacteria by polymerase chain reaction and DNA hybridization. FEMS Microbiol. Lett. 1999, 173, 255-263. [CrossRef] [PubMed]

54. Han, G.; Lan, J.; Chen, Q.; Yu, C.; Bie, S. Response of soil microbial community to application of biochar in cotton soils with different continuous cropping years. Sci. Rep. 2017, 7, 10184. [CrossRef] [PubMed]

55. Sarkar, A.; Ghosh, P.K.; Pramanik, K.; Mitra, S.; Maiti, T.K. A halotolerant enterobacter sp. displaying acc deaminase activity promotes rice seedling growth under salt stress. Res. Microbiol. 2017, 169, 20-32. [CrossRef] [PubMed]

56. Liu, N.; Shao, C.; Sun, H.; Liu, Z.; Guan, Y.; Wu, L.; Zhang, L.; Pan, X.; Zhang, Z.; Zhang, Y.; et al. Arbuscular mycorrhizal fungi biofertilizer improves American ginseng (Panax quinquefolius L.) growth under the continuous cropping regime. Geoderma 2020, 363, 114155. [CrossRef]

57. Abujabhah, I.S.; Doyle, R.B.; Bound, S.A.; Bowman, J.P. Assessment of bacterial community composition, methanotrophic and nitrogen-cycling bacteria in three soils with different biochar application rates. J. Soils Sediment. 2017, 18, 148-158. [CrossRef] 